\title{
Activin Potentiates Proliferation in Mature Avian Auditory Sensory Epithelium
}

\author{
Jennifer S. McCullar, Sidya Ty, Sean Campbell, and Elizabeth C. Oesterle \\ Department of Otolaryngology-Head and Neck Surgery, Virginia Merrill Bloedel Hearing Research Center, University of Washington, Seattle, Washington \\ 98195-7923
}

\begin{abstract}
Humans and other mammals are highly susceptible to permanent hearing and balance deficits due to an inability to regenerate sensory hair cells lost to inner ear trauma. In contrast, nonmammalian vertebrates, such as birds, robustly regenerate replacement hair cells and restore hearing and balance functions to near-normal levels. There is considerable interest in understanding the cellular mechanisms responsible for this difference in regenerative capacity. Here we report on involvement of the TGF $\beta$ superfamily type II activin receptors, $A c v r 2 a$ and $A c v r 2 b$, in regulating proliferation in mature avian auditory sensory epithelium. Cultured, posthatch avian auditory sensory epithelium treated with Acvr2a and Acvr2b inhibitors shows decreased proliferation of support cells, the cell type that gives rise to new hair cells. Conversely, addition of activin A, an Acvr2a/b ligand, potentiates support cell proliferation. Neither treatment (inhibitor or ligand) affected hair cell survival, suggesting a specific effect of Acvr2a/b signaling on support cell mitogenicity. Using immunocytochemistry, Acvr2a, Acvr2b, and downstream Smad effector proteins were differentially localized in avian and mammalian auditory sensory epithelia. Collectively, these data suggest that signaling through Acvr2a/b promotes support cell proliferation in mature avian auditory sensory epithelium and that this signaling pathway may be incomplete, or actively blocked, in the adult mammalian ear.
\end{abstract}

\section{Introduction}

In 2006, 37 million adults in the United States reported hearing difficulties, an increase of 5.5 million in only 6 years (Pleis et al., 2003; Pleis and Lethbridge-Cejku, 2006). There is growing concern that these numbers may continue to rise due to increased and prolonged use of personal listening devices such as MP3 players. Most acquired and congenital hearing loss and balance disorders result from the loss of sensory hair cells (HCs), specialized cells responsible for the detection of sound and motion. Because auditory HCs are not regenerated in mature mammals (Sobkowicz et al., 1992; Roberson and Rubel, 1994; Chardin and Romand, 1995), the damage is cumulative and permanent. In contrast, auditory organs of nonmammalian vertebrates replace HCs lost to insult. The new HCs are generated by epithelial support cells (SCs), either through renewed proliferation or by direct phenotypic change (for review, see Oesterle and Stone, 2008). These newly generated HCs are properly innervated, nearly completely restoring auditory and vestibular functions (for review, see Cotanche, 1999; Smolders, 1999; Bermingham-McDonogh and Rubel, 2003). Identifying the signaling pathways that under-

\footnotetext{
Received 0ct. 15, 2009; accepted Nov. 12, 2009.

This research was supported by National Institute on Deafness and Other Communication Disorders (NIDCD) R01 Grant DC03944, NIDCD P30 Grant DC04661, National Institute of Child Health and Human Development P30 Grant HD002274, NIDCD T32 Grant DC005361, and the Hearing Regeneration Initiative. We thank the reviewers for their time and thoughtful comments, Glen MacDonald for help with ImageJ, Drs. Robin Gibson and Jennifer Stone for help with qRT-PCR, and Drs. Allison Coffin, Clifford Hume, Kelly Owens, Rémy Pujol, Edwin Rubel, and Yuan Wang for helpful conversations and comments.

Correspondence should be addressed to Elizabeth C. Oesterle, Department of Otolaryngology-Head and Neck Surgery, Virginia Merrill Bloedel Hearing Research Center, Center on Human Development and Disability CD176, Box 357923, University of Washington, Seattle, WA 98195-7923. E-mail: oesterle@uw.edu.

D0I:10.1523/JNEUROSC1.5154-09.2010

Copyright $\odot 2010$ the authors $\quad 0270-6474 / 10 / 300478-13 \$ 15.00 / 0$
}

lie SC proliferation in the nonmammalian vertebrate ear is critical for the development of future therapies to induce regenerative repair in humans.

Mitogenic agents for mature auditory sensory epithelium (SE) in both nonmammalian and mammalian ears remain elusive. Growth factors have been identified that enhance SC proliferation in mature mammalian vestibular SE, but effects are modest (Lambert, 1994; Yamashita and Oesterle, 1995; Kuntz and Oesterle, 1998; Gu et al., 2007). Given the well documented roles of the transforming growth factor $\beta$ (TGF $\beta$ ) superfamily in regulating regenerative proliferation in a variety of tissues, this family is a likely candidate in regulating proliferation in the nonmammalian vertebrate $\mathrm{SE}$.

The TGF $\beta$ superfamily consists of 5 type II receptors (TGF $\beta$ RII, Acvr2a, Acvr2b, BMPRII, MISRII), 7 type I receptors (activin receptor-like kinases 1-7), and over 30 secreted cytokines including TGF $\beta$ s, activins, bone morphogenic proteins (BMPs), and growth differentiation factors (GDFs) (for review, see Massagué and Gomis, 2006). Activated heterodimerized receptors phosphorylate downstream Smad signaling proteins. We examined signaling of the activin receptors Acvr2a and Acvr2b (also called ActRIIA and ActRIIB, respectively), a TGF $\beta$ type II receptor subclass, and their associated ligands. Acvr2a/b signaling is known to regulate regenerative proliferation in many tissues after injury, including sensory, epithelial, and neurosensory tissues (for review, see Chen et al., 2006; Wiater and Vale, 2008). We hypothesized that Acvr2a/b signaling regulates proliferation in the mature auditory sensory epithelium.

The following work shows localization of activin type II receptors and Smads $1 / 5 / 8$ and $2 / 3$ in mature avian auditory SE and demonstrates that exogenous regulation of activin signaling in- 
fluences SC proliferation in vitro. Blocking Acvr2a and Acvr2b signaling in cultured avian auditory epithelium inhibits SC proliferation, whereas treatment with an activin receptor agonist increases proliferation. Our delineation of activin receptor expression patterns in mouse auditory and vestibular SE shows marked differences between avian and mammalian tissues. Together, these data support a role for activin type II receptors in the proliferative responsiveness of avian auditory sensory epithelia.

\section{Materials and Methods}

Animals. All animal care procedures and experimental methods were approved by the Institutional Animal Care and Use Committee at the University of Washington. Fertilized eggs or 1-d-old White Leghorn chickens (Gallus domesticus) were purchased from Hyline International. Eggs were placed in a humidified incubator at $37^{\circ} \mathrm{C}$ until hatching. Hatchlings were housed in heated brooders with ample food and water in an animal care facility at the University of Washington until use at posthatch day 7 to day 14 (P7-P14). Adult (6 weeks or older) outbred Swiss Webster mice purchased from Harlan were housed in an animal care facility at the university until use.

Organotypic culture. Cochlear ducts were isolated and cultured as previously described with minor adjustments (Oesterle et al., 1993, 2000). Cochlear ducts without the tegmentum vasculosum were placed free floating, one duct per well, into 24-well tissue culture plates with $0.5 \mathrm{ml}$ of DMEM, $0.5 \%$ fetal bovine serum (Atlanta Biologicals), and the cell proliferation marker 5-bromo-2'-deoxyuridine (BrdU; $1 \mu \mathrm{M}$, Sigma). Cultures were treated with Fc:Acvr2a and Fc:Acvr2b (chimeric proteins of the activin receptor extracellular domain fused to Fc domain of IgG to maintain solubility) or the ligand activin A [catalog numbers (Cat. Nos.) 340-R2, 339-RB, and 338-AC, respectively; R\&D Systems]. Treated and control organs were cultured for $3 \mathrm{~d}$ at $37^{\circ} \mathrm{C}$ in a $5 \% \mathrm{CO}_{2}$ atmosphere. Culture medium was changed daily for the experiments with soluble receptors. Untreated control cochlear ducts were cultured identically. After culture, tissues were fixed by immersion in buffered $4 \%$ paraformaldehyde (0.1 M phosphate buffer, $\mathrm{pH} 7.4$ ) for $30 \mathrm{~min}$, rinsed with PBS, and stored at $4^{\circ} \mathrm{C}$ before immunofluorescence labeling.

Antibodies. Polyclonal antibodies (rabbit) to pSmad1/5/8, pSmad2, and pSmad 3 used routinely in chicken and mice (Rios et al., 2004, Franke et al., 2006; Rajagopal et al., 2007, Montero et al., 2008) were purchased from Cell Signaling Technologies (Cat. Nos. 9511, 3104, and 9520, respectively) and used at a 1:100 dilution (Franke et al., 2006). Affinitypurified rabbit antisera specific for Acvr2a and Acvr2b were generously gifted by Dr. Wylie Vale (Salk Institute, San Diego, CA) and used at 1:200-1:400 (Mathews and Vale, 1993; Kos et al., 2001). A polyclonal antibody (goat) to the transcription factor Sox 2 was obtained from Santa Cruz Biotechnology (SC-17320) and used at 1:500 to label auditory SCs (Oesterle et al., 2008). Monoclonal rat anti-BrdU (Accurate Chemical Scientific; clone BU1/75, Cat. No. OBT0030G) was used at 1:300 to label proliferating cells that pass through $S$ phase. Two antibodies were used to label HCs, a mouse monoclonal anti-parvalbumin antibody (parv19, Cat. No. P3088, Sigma, 1:1000) (Sage et al., 2000) and a rabbit anti-pig myosin VI polyclonal antibody from Proteus Biosciences (Cat. No. 256791, 1:500) (Hasson and Mooseker, 1994; Hasson et al., 1997). All primary antibodies listed above have been used previously in chickens and/or mice (Kos et al., 2001; Rios et al., 2004; Goldstein et al., 2005; Reynolds et al., 2005; Franke et al., 2006; Hume et al., 2007; Oesterle et al., 2008). Secondary antibodies with fluorescent labels (Alexa 488, 568, 594) were purchased from Invitrogen/Molecular Probes and used at manufacturer-recommended dilutions (1:200-1:500).

Western blots. Cochlear ducts were removed from the head and immediately placed in $50 \mu \mathrm{l}$ of SDS-PAGE loading buffer $(62.5 \mathrm{~mm}$ Tris- $\mathrm{HCl}$, pH 6.8, 5 mм EDTA, 350 mм DTT, 25\% glycerol, $0.01 \%$ bromophenol blue, and $2 \%$ SDS). Two ducts from two different animals were in each aliquot, which was frozen at $-80^{\circ} \mathrm{C}$ until use. Cell disruption and solubilization were accomplished by incubating for $10 \mathrm{~min}$ at $100^{\circ} \mathrm{C}$ and centrifuging at 14,000 rpm (Eppendorf microcentrifuge) for $5 \mathrm{~min}$ to remove cellular debris. Samples were run on a precast $4-20 \%$ gradient gel with one lane for Precision Plus protein standards (Bio-Rad) using
Tris-glycine running buffer (25 mm Tris, $190 \mathrm{~mm}$ glycine, 0.1\% SDS). The proteins were transferred from the gel by electroblotting onto a PVDF membrane (Bio-Rad) that had soaked in methanol for $1 \mathrm{~min}$ and equilibrated in transfer buffer (25 mM Tris base, $190 \mathrm{~mm}$ glycine, 20\% methanol, and $0.005 \%$ SDS). After transfer, the membrane was blocked in $5 \%$ milk in TBS with $0.1 \%$ Tween (TBST) for $1 \mathrm{~h}$ and then incubated in primary antibody overnight $(1: 500)$ at $4^{\circ} \mathrm{C}$. Secondary HRPconjugated antibody (1:5000) incubation was for $2 \mathrm{~h}$ at room temperature. The membrane was washed in TBST before incubation with the chemiluminescent detection reagents (Bio-Rad) for $5 \mathrm{~min}$. Blots were exposed to film and developed.

Quantitative real-time PCR. To establish the presence of activin A ligand in posthatch chicken auditory sensory epithelium, cDNA from auditory sensory epithelia collected from normal chickens (P5-P10) or chickens $4 \mathrm{~d}$ after gentamicin treatment (to kill auditory HCs) was used. This cDNA was generously gifted by Dr. Jennifer Stone (University of Washington, Seattle, WA), and its preparation is described in the study by Daudet et al. (2009). The primer sets used for activin A (activin $\beta_{\mathrm{A}}$ ) were $5^{\prime}$-GCCTGAGATGGTGGAAGCA-3' and $5^{\prime}$ CGGCTGGGTGATGTTAGGTC-3' , primers for Beta-tectorin (positive control) were 5' -GGCCCTGCACTCCAAATAAA-3' and 5' -AGCTGATTGACCTCCCATCC- $3^{\prime}$, and primers for $\beta$-actin were $5^{\prime}$-CCGTGCTGTGTTCCCATCT- $3^{\prime}$ and $5^{\prime}$-TGCTCTGGGCTTCATCACC- ${ }^{\prime}$. The expression of activin A was normalized to the expression of $\beta$-actin. SYBR Green-based master mix (Bio-Rad) was used for the PCRs, and negative control reactions lacked cDNA and/or primers. Amplification was performed using an iCycler (Bio-Rad).

Cryosectioning. The ventral surface of the cochlear ducts in P7-P14 chickens was exposed before immersing the head in ice-cold fixative (4\% paraformaldehyde in $0.1 \mathrm{M}$ phosphate buffer) for $2 \mathrm{~h}$. After fixation, heads were washed in PBS (three times over $30 \mathrm{~min}$ ), and the cochlear ducts were isolated. To obtain cryosections, tissues were sequentially immersed in 10\% sucrose (in PBS) for $1 \mathrm{~h}, 15 \%$ sucrose for $1 \mathrm{~h}$, and 1:1 mix of 15\% sucrose/Tissue Tek Optimal Cutting Temperature compound (OCT; VWR International) overnight. Cochlear ducts in OCT were placed into plastic freezing trays under vacuum for $15 \mathrm{~min}$ to remove air bubbles from the freezing compound. The ducts were then frozen rapidly in a dry ice ethanol bath and stored at $-80^{\circ} \mathrm{C}$ until sectioning. Cochlear ducts were cut into $10 \mu \mathrm{m}$ sections on a Leica CM1850 cryostat, mounted serially onto Platinum Superfrost $(+)$ slides (Mercedes Medical), and stored at $-80^{\circ} \mathrm{C}$ before immunofluorescence labeling.

Temporal bones from adult mice were directly perfused with fixative (4\% paraformaldehyde in $0.1 \mathrm{~m}$ phosphate buffer) through the oval window after removal of the stapes and perforation of the apex of the cochlea. The temporal bones were then immersed in the same fixative at room temperature for 2-4 h. After several washes in PBS, they were decalcified for 15 min with RDO Rapid Decalcifier (Apex Engineering Products) at room temperature. After several additional PBS rinses, they were sequentially incubated with sucrose solutions and OCT (10\% sucrose, $30 \mathrm{~min}$; 15\% sucrose, overnight; 1:1 15\% sucrose:OCT, overnight; 100\% OCT overnight). Before rapid freezing with dry ice, temporal bones were placed under vacuum for $15 \mathrm{~min}$. Like the avian cochlear duct, mammalian tissue was cut into $10 \mu \mathrm{m}$ sections with a cryostat, mounted onto Platinum Superfrost $(+)$ slides, and stored at $-80^{\circ} \mathrm{C}$.

Immunofluorescence labeling. All steps were performed at room temperature unless otherwise stated. Slides with cryosections were dried at $37^{\circ} \mathrm{C}$ for $30 \mathrm{~min}$ and incubated for $30 \mathrm{~min}$ in PBS with $0.1 \%$ Triton X-100 and $2 \mathrm{mg} / \mathrm{ml}$ bovine serum albumin to make membranes more permeable to antibodies. To prevent nonspecific binding of primary antibody, tissues were incubated for $1 \mathrm{~h}$ in a blocking solution consisting of $5 \%$ normal serum $/ 0.1 \%$ Triton X-100/2 $\mathrm{mg} / \mathrm{ml}$ bovine serum albumin in PBS. Primary antibody incubations were performed overnight at $4^{\circ} \mathrm{C}$ in PBS, $5 \%$ serum, $2 \mathrm{mg} / \mathrm{ml}$ bovine serum albumin, and $0.1 \%$ Triton $\mathrm{X}-100$. Fluorescence-labeled secondary antibodies (Alexa 488, 568, 594, Invitrogen) were used at a dilution of 1:300 in blocking buffer for $4 \mathrm{~h}$ at room temperature or overnight at $4^{\circ} \mathrm{C}$. Labeling with multiple primary antibodies was done sequentially. The tissues labeled with BrdU-specific antibodies were incubated in $2 \mathrm{~N} \mathrm{HCl}$ in $0.1 \%$ Triton-X/PBS buffer for 30 
min to denature the DNA before application of blocking solution. Following final secondary antibody incubation, tissues were incubated for 15 min with 4',6-diamidino-2phenylindole (DAPI, Cat. No. D9542, SigmaAldrich, $1 \mu \mathrm{g} / \mathrm{ml})$, a fluorescent stain that binds DNA to label nuclei. After being rinsed in PBS, sections were coverslipped with Vectashield mounting medium. Whole-mount tissues were processed identically except that (1) the tectorial membrane was removed mechanically before processing the tissue, and (2) blocking solution and antibody incubations also included $0.03 \%$ saponin.

Controls for immunofluorescence. Method and antibody specificity were checked by substituting nonimmune sera for the primary antibody (block-only incubation) and using a series of dilutions of the primary antibody. In double-labeling experiments, antibodies raised in different species were used to avoid crossreactivity among secondary antibodies.

Microscope imaging. Whole-mount preparations and cryostat sections were viewed with an Olympus FV-1000 laser scanning confocal microscope, equipped with $405 \mathrm{~nm}$ diode, 457, 488 , and $514 \mathrm{~nm}$ multiline argon, $543 \mathrm{~nm}$ helium neon, and $637 \mathrm{~nm}$ helium neon lasers. Fluoview version $1.04 \mathrm{a}$ acquisition software was used. Sequential image acquisition was performed when bleed-through between channels was an issue. Files were imported into ImageJ 1.42a (NIH) and/or Adobe Photoshop CS version 8 (Adobe) for processing and analysis. Histogram stretch was performed on each image with Photoshop to increase the contrast of immunofluorescence against background. Control and experimental images were treated the same in all instances.

Cell quantitation. Methods for quantifying proliferating SCs in whole-mount preparations of cultured tissue are similar to those described previously (Oesterle et al., 2000), except Sox2/ BrdU double labeling and confocal laser scanning microscopy were used to identify proliferating SCs (Sox ${ }^{+} / \mathrm{BrdU}^{+}$cells) (Fig. $1 D$, arrow), nonproliferating SCs (Sox $2^{+} / \mathrm{BrdU}^{-}$cells) (Fig. $1 D$ ), and $\mathrm{HCs}$ (Sox ${ }^{-}$cells located above the SC layer with large, round nuclei) (Fig. 1C). In mature auditory SE, the transcription factor Sox 2 is expressed specifically in SC nuclei and is not detectable in HCs (Oesterle et al., 2008). Whole-mount preparations of chicken auditory SE, the basilar papilla, were imaged on a confocal microscope. The apical three-fourths of the basilar papilla, in which the tissue lies relatively flat and accurate cell counts are possible, was divided into five regions (Fig. $1 A$, regions $\mathrm{A}$ to $\mathrm{E}$ ). Each region was further subdivided into four smaller quadrants (Fig. $1 B$, quadrants 1-4). A quadrant was selected randomly for each papilla before imaging and was consistent for all five regions imaged. One confocal $z$ series through the depth of the sensory epithelium, in $1 \mu \mathrm{m}$ steps oriented parallel to the lumen, was collected from the five regions at $60 \times(20 \times$ lens with a zoom of 3). The area of each region was quantified with NIH ImageJ and equaled $0.045 \mathrm{~mm}^{2}$. Basilar papillae that sustained significant mechanical damage to the SE in two or more regions were discarded.

A single experimenter using the Cell Counter plug-in for ImageJ determined cell density estimates for each region. Mean values were calculated for each experimental paradigm in the following manner: overall mean $=$ mean for regions $\mathrm{A}+\mathrm{B}+\mathrm{C}+\mathrm{D}+\mathrm{E}$; apex $=\mathrm{A}+\mathrm{B}$; mid-apex $=\mathrm{C}+$ $\mathrm{D}$; mid-base $=\mathrm{E}$; neural $=\mathrm{A}+\mathrm{C}$; and abneural $=\mathrm{B}+\mathrm{D}$. Means for the apex, mid-apex, and mid-base regions facilitate examination of an apical-to-basal frequency gradient. Means for the neural and abneural regions facilitate examination of an abneural-to-neural (inferior-tosuperior) gradient. Total numbers of proliferating SCs $\left(\operatorname{Sox} 2^{+} /\right.$
$\mathrm{BrdU}^{+}$cells), HCs (Sox $2^{-}$cells), and SCs (Sox ${ }^{+}$cells) were quantified in the regions described above. In cultured tissue, estimates of HC density, SC density, and proliferating SC density were all obtained from the same confocal files to facilitate cell type comparisons. For freshly dissected (noncultured) tissue, HC density and SC density estimates were simultaneously obtained from confocal files collected from regions A to E in eight papillae.

Statistics. Significance values were determined using one-way ANOVAs or Student's $t$ tests (Prism, GraphPad Software). $p \leq 0.05$ was considered statistically significant.

\section{Results}

Activin receptors are expressed in support cells and hair cells in mature avian auditory sensory epithelium

TGF $\beta$ family members have been implicated in regulating stem/ progenitor cell proliferation in a variety of mature cell types (Kawase et al., 2004; Son et al., 2005; Giannouli and Kletsas, 2006; Jaźwińska et al., 2007). They can positively or negatively regulate proliferation, but are best known for their ability to inhibit cell proliferation (Li et al., 1998; Massagué et al., 2000; McCroskery et al., 2003). Avian auditory SE is quiescent in the undamaged state; however, it has a robust ability to regenerate HCs lost to injury or damage [for review, see Corwin and Oberholtzer (1997); Stone and Cotanche (2007)]. We hypothesized that TGF $\beta$ signaling has a role in regulating $\mathrm{HC}$ progenitor (SCs with mitotic potential) proliferation in mature inner ear SE. Because there is an enormous convergence in signaling of TGF $\beta$ superfamily ligands 


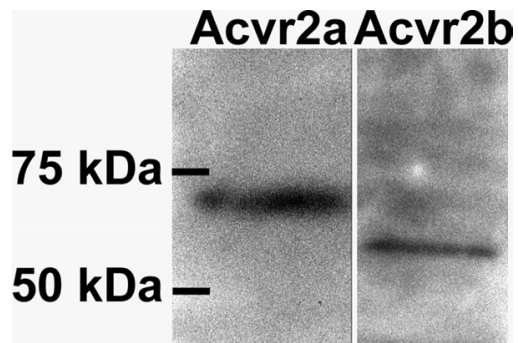

Figure 2. Western blot analysis of activin receptor antibodies used for this study. Figure shows representative Western blots of Acvr2a (left) and Acvr2b (right) in cochlear ducts taken from normal P10 chicks. Immunoblots are of solubilized extracts from two cochlear ducts (from 2 different animals) per lane. The results indicate that the activin receptors are expressed in the chicken cochlear duct and are detectable as single specific bands corresponding to the molecular weights of $\sim 66$ and $72 \mathrm{kDa}$, respectively.
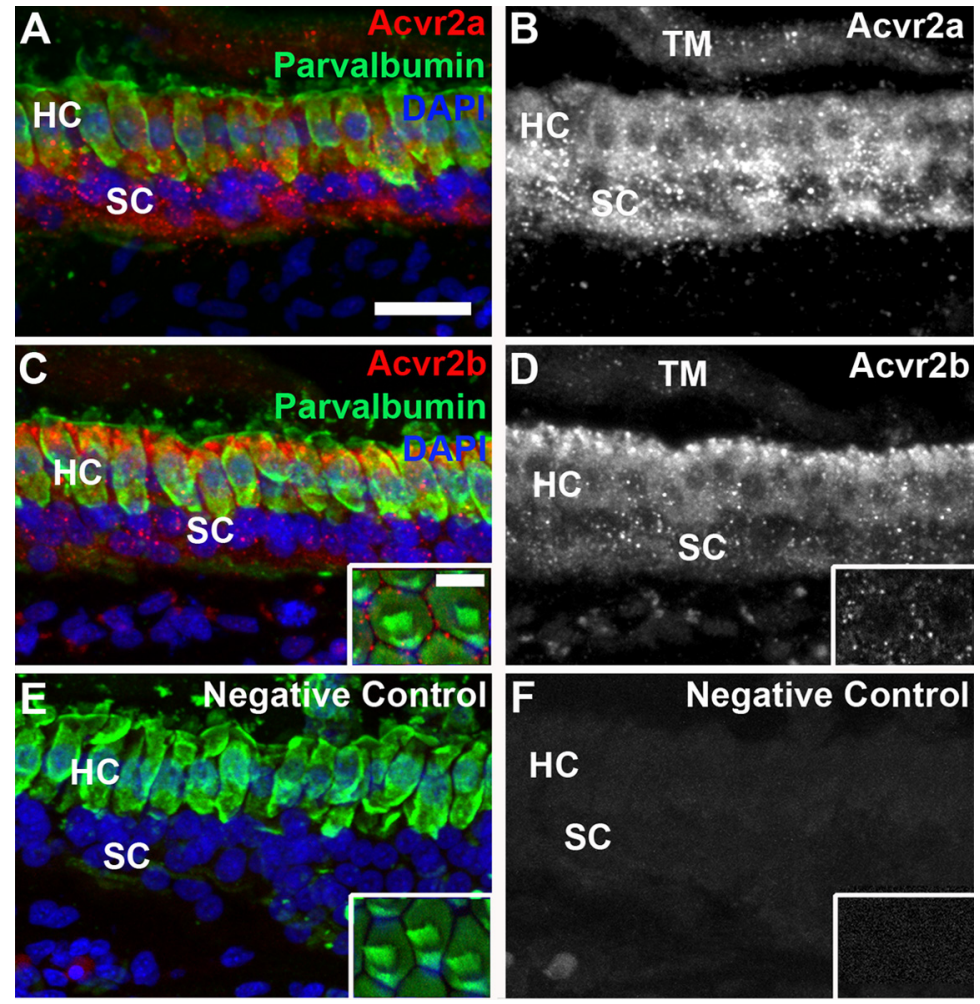

Figure 3. Activin receptors are expressed in support cells and hair cells in mature chicken auditory sensory epithelium. Cryostat sections and whole-mount preparations of auditory sensory epithelium from P7-P14 chickens imaged with confocal microscopy. Cryostat sections are from the apical region and images from whole-mount preparations are from the mid-base region of the papillae. Left panels $(\boldsymbol{A}, \boldsymbol{C})$ are labeled with antibody specific to $A c v r 2 a(\boldsymbol{A}$, red) or $A c v r 2 b(\boldsymbol{C}$, red), an antibody specific to the $H C$ marker parvalbumin (green), and the nuclear counterstain DAPI (blue). Right panels $(\boldsymbol{B}, \boldsymbol{D})$ are the red channels alone (receptorspecific antibody) in grayscale. $\boldsymbol{A}, \boldsymbol{B}, \mathrm{Acvr} 2$ a protein is expressed in SCs and HCs. Some nonspecific labeling is seen in the tectorial membrane (TM). C, D, Acvr2b protein is expressed in support cells and hair cells. $\boldsymbol{C}$, Inset, Lumenal surface of the epithelium. Stereociliary bundles can be seen on hair cell surfaces. Note the punctate Acvr2a labeling (red) in apical processes of support cells in between the hair cells. $\boldsymbol{E}, \boldsymbol{F}$, Negative control tissue processed identically to experimental tissue, except it was not exposed to primary antibody for Acvr2a or Acvr2b. Control tissue was imaged at the same conditions set for digital capture as those for the experimental tissue. Scale bars: (in $\boldsymbol{A}) \boldsymbol{A}-\boldsymbol{F}, 20 \mu \mathrm{m}$; (in $\boldsymbol{C}$, inset) $\boldsymbol{C}-\boldsymbol{F}$, insets, $10 \mu \mathrm{m}$.

through only 5 type II receptors, posthatch chicken auditory SE was first screened by immunocytochemistry for expression of TGF $\beta$ type II receptors. Initial screens showed Acvr2a and Acvr2b expression in critical cell types (i.e., in SCs), and Western blot analyses demonstrated specificity of antibody with the detection of a single band (Fig. 2). Thus, Acvr2a and Acvr2b expression patterns were further delineated by performing fluorescence immunocytochemistry on cryosections and whole-mount prepara- tions of adult SE taken from normal posthatch chickens. As yembrane of auditory HCs in all frequency reshort HCs. Support cells throughout the papilla also show Acve throughout the papilla. The Acvr2b immunoreactivity is strong near the lumenal surface of the SCs (Fig. $3 C, D$, insets), but is also Smads, downstream effectors of Acvr2a and Acvr2b signaling, are expressed in support cells and hair cells in mature avian auditory $\mathrm{SE}$

Acvr2a and/or Acvr2b can heterodimerize with multiple TGF $\beta$ type I receptors (for review, see Wrana et al., 2008). Activation of specific receptor heterodimer combinations leads to phosphorylation of two families of intracellular receptor-associated Smad proteins, grouped by sequence homology, Smad2/3 (also called Smad2/Smad3) or Smad 1/5/8 (also called Smad1/Smad5/ Smad8) (for review, see Heldin, 2008). Once activated, the receptor-associated Smads are translocated to the nucleus to affect transcription of target genes (for review, see Xu, 2006; Massagué et al., 2005). In light of activin receptor expression in the sensory epithelium, we hypothesized that one or both families of receptorassociated Smads, Smad2/3 or Smad1/5/8, are present in SCs and HCs. Activin receptors are best characterized for their signaling through Smad2/3, but some activin receptor ligands (e.g., BMPs) activate signaling through Smad1/5/8 (for review, see Tsuchida et al., 2007). Using fluorescence immunocytochemistry, we identified which receptor-associated Smads were present in normal posthatch chicken auditory SE. Immunoreactivity to phosphorylated (active) Smad2 (pSmad2) is detectable in SC and HC nuclei (Fig. 4A,B). pSmad2 is expressed in all SC nuclei and in all $\mathrm{HC}$ types. pSmad2 immunoreactivity is also present in spiral ganglion cell nuclei (data not shown). In contrast, pSmad3 is undetectable in posthatch chicken auditory SE (Fig. 4C,D), suggesting that signaling through Smad3 is not active in the normal quiescent tissue. Activated Smad1/5/8 (pSmad1/5/8) proteins were detected with an antibody that recognizes a conserved carboxy-terminal phosphorylation domain in all three proteins. pSmad1/5/8 proteins are expressed in SC and $\mathrm{HC}$ nuclei throughout the papilla (Fig. $4 E, F)$. Spiral ganglion nuclei are also immunopositive (data not shown). Expression patterns of the receptor Smads and activin receptors are summarized in Table 1 . The presence of these receptors and their downstream effectors in normal SE is supportive evidence that activin signaling may be relevant to normal avian auditory physiology. 

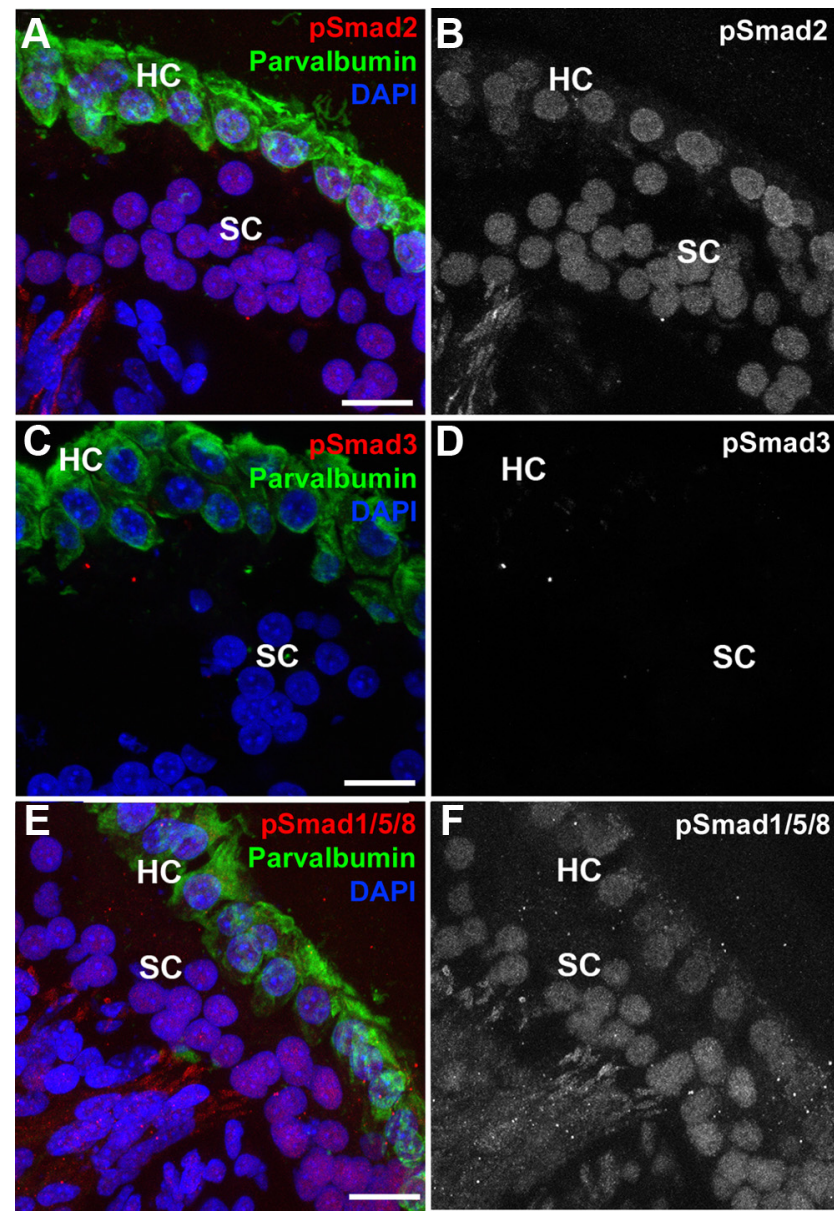

Figure 4. Smad protein expression in mature chicken auditory sensory epithelium. Cryostat sections of auditory sensory epithelium from P7-P14 chickens imaged with confocal microscopy. Left panels are labeled with antibody specific to pSmad2 $(\boldsymbol{A}$, red), pSmad3 ( $\boldsymbol{C}$, red), and $\mathrm{pSmad1/5/8}(\boldsymbol{E}$, red), an antibody specific to the HC marker parvalbumin (green), and the nuclear counterstain DAPI (blue). Right panels are the red channels (Smad-specific antibody) alone in grayscale. $\boldsymbol{A}, \boldsymbol{B}, \mathrm{pSmad} 2$ is expressed in $\mathrm{SC}$ and $\mathrm{HC}$ nuclei. $\boldsymbol{C}, \boldsymbol{D}, \mathrm{pSmad} 3$ expression is undetectable in posthatch chicken auditory SE. $\boldsymbol{E}, \boldsymbol{F}, \mathrm{pSmad} 1 / 5 / 8$ is expressed in support cell and hair cell nuclei. Scale bars: $10 \mu \mathrm{m}$.

Table 1. Localization of activin receptor signaling proteins in chicken auditory SE

\begin{tabular}{llllll}
\hline & Acvr2a & Acvr2b & pSmad2 & pSmad3 & pSmad1/5/8 \\
\hline Hair cells & ++ & ++ & ++ & - & ++ \\
Support cells & ++ & + & ++ & - & ++
\end{tabular}

++ , Strongly expressed; + , weakly expressed; - , not detected. Three to five basilar papillae were examined for each test protein.

\section{Organotypic culture model for studying signaling effects on proliferation}

To determine whether activin receptors play a role in regulating $\mathrm{HC}$ progenitor proliferation, activin signaling was manipulated in organotypic cultures of posthatch chicken auditory SE. Pertinent aspects of the culture system are described below, before the pharmacological manipulations and their effects are discussed. Some unavoidable spontaneous HC loss occurs in the cultured auditory epithelium (Frenz et al., 1998; Cheng et al., 2003), likely due to mechanical and metabolic trauma that occurs upon removal of the tissue from its normal environment and maintaining it in culture. Sound-, laser-, or ototoxic drug-induced HC death stimulates SC proliferation in in situ avian auditory SE (Corwin and Cotanche, 1988; Ryals and Rubel, 1988; Girod et al.,
1989; Tucci and Rubel, 1990; Warchol and Corwin, 1996). Spontaneous SC proliferation has been previously reported in organotypic cultures of normal posthatch chicken basilar papilla (Oesterle et al., 1993; Warchol and Corwin, 1996); however, the amount and spatial patterns of SC proliferation and its relationship to culture-induced $\mathrm{HC}$ loss have not been well characterized. We describe the culture-induced damage by comparing $\mathrm{HC}$ and SC numbers in cultured versus "fresh" (fixed without culturing) tissue. Further, we determined whether the magnitude of SC proliferation is correlated to culture-induced HC loss. Support cell proliferation was determined by BrdU uptake, which labels cells that enter the $S$ phase of the cell cycle and their progeny (Gratzner, 1982).

Normal untreated cochlear ducts were isolated and placed free floating into culture medium supplemented with $\operatorname{BrdU}(n=32)$. After $3 \mathrm{~d}$ of in vitro growth, the tissues were fixed and immunolabeled for BrdU and Sox2 and counterstained with the nuclear marker DAPI. Antibodies to the transcription factor Sox2 label SCs, but not HCs, and facilitate quantification of both HCs and SCs in auditory SE (Oesterle et al., 2008). Twelve freshly dissected and fixed cochlear ducts were labeled concurrently with, and identically to, the cultured tissue. Hair cells were counted in five regions of the apical three-fourths of each organ, regions $\mathrm{A}$ to $\mathrm{E}$ (as described in Fig. 1). The basilar papilla, similar to the mammalian organ of Corti, is tonotopically organized; low-frequency sounds are encoded by HCs in the apical (distal) region, and high-frequency sounds are encoded in the basal (proximal) region (Ryals and Rubel, 1982). High-frequency HCs are more susceptible to insult than low-frequency HCs (Ryals and Rubel, 1985b; Tucci and Rubel, 1990; Girod et al., 1991). Consequently, we expected the spontaneous culture-induced $\mathrm{HC}$ loss to progress along the tonotopic frequency gradient, with the basal region suffering the most culture-induced $\mathrm{HC}$ loss. As shown in Figure $5 A, \mathrm{HC}$ density decreases apically to basally in the organotypic cultures relative to fresh organs. HC density is also decreased in both the abneural and neural regions of the cultured organs (Fig. 5B). Overall, mean HC density differs significantly in fresh versus cultured tissue $(1.3 \pm 0.1$ vs $0.7 \pm 0.1$ SEM. HCs $/ 100$ $\left.\mu \mathrm{m}^{2} \mathrm{SE}, p<0.0001\right)$. Approximately $58 \%$ of the HCs remain in the cultured tissue after $3 \mathrm{~d}$ in vitro, similar to the $55 \%$ reported by Cheng et al. (2003) following $2 \mathrm{~d}$ of in vitro growth. Regarding our estimate of $\mathrm{HC}$ density for normal (fresh) chicken papillae, our values (range $=1.0-1.3 \mathrm{HCs} / 100 \mu \mathrm{m}^{2}$; average $=1.3 \mathrm{HCs} /$ $100 \mu \mathrm{m}^{2}$ ) are harmonious with reports for 6-week-old and embryonic day 12 chickens (Duckert and Rubel, 1993; Goodyear and Richardson, 1997), but are slightly higher than estimates for P5-P10 chickens (Frenz et al., 1998; Cheng et al., 2003; average of 0.65 and $0.83 \mathrm{HCs} / 100 \mu \mathrm{m}^{2}$, respectively).

Support cell density was also examined in a subset of the organs used for the HC analysis described above. The basalapical and abneural-neural characteristics of SC density were calculated for eight freshly dissected and eight cultured organs. Support cell densities are similar across all regions in both fresh and cultured organs. These data are summarized in Tables 2 and 3, along with density estimates for HCs and proliferating SCs $\left(\mathrm{BrdU}^{+} / \mathrm{Sox} 2^{+} \mathrm{SCs}\right)$ that were obtained concurrently. While there is some HC loss in the apex of the cultured organs (Fig. 5A) $(p<0.05)$, average SC density is equivalent when compared with fresh tissue, and SC:HC ratios remain similar. In contrast, marked $\mathrm{HC}$ loss is seen in the mid-base region of cultured organs $(p<0.0001)$, resulting in a fourfold difference in the SC:HC ratio (noncultured tissue $=$ 

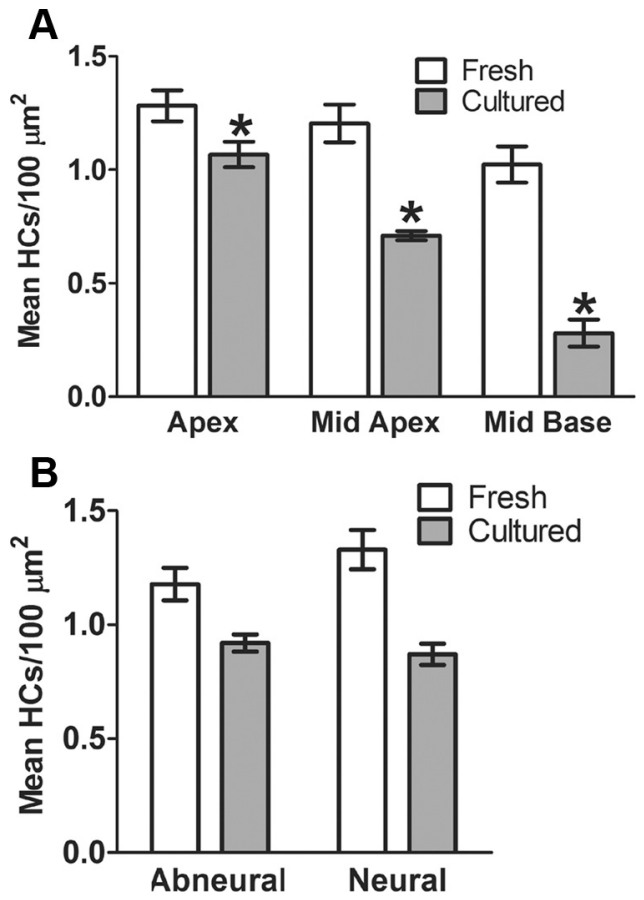

Figure 5. Quantification of hair cell loss in organotypic cultures of normal posthatch chicken auditory sensory epithelium. Hair cell counts were obtained from freshly dissected basilar papillae $(n=12)$ and untreated (control) basilar papillae grown in culture for $3 \mathrm{~d}(n=32)$ that were immunolabeled for the SC-specific marker Sox2. Hair cells were identified as Sox2 ${ }^{-}$cells with distinct large round nuclei residing in the lumenal portion of the epithelium, above the support cell nuclear layer. Counts were obtained from five regions of the basilar papillae as described in Figure 1, and the average hair cell density was computed for the apex (regions A and $B)$, mid-apex (C and D), and mid-base (E). Average hair cell density was also computed for the abneural ( $B$ and $D$ ) and neural $(A$ and $C$ ) regions. Each data value represents the mean \pm SEM. $\boldsymbol{A}$, Apical-basal gradient of HC density. $\boldsymbol{B}$, The abneural-neural gradient. Asterisk indicates significance from fresh tissue at the 0.05 level.

2.7 ; cultured tissue $=10.0$ ) that is mainly attributable to the difference in HC density.

We hypothesized that the magnitude of spontaneous cultureinduced HC loss and SC proliferation are correlated in control (untreated) organotypic cultures. Numbers of proliferating SCs $\left(\mathrm{BrdU}^{+} / \mathrm{Sox}^{+}\right.$cells) were quantified and compared with HC numbers. $\mathrm{BrdU}^{+} / \mathrm{Sox} 2^{-}$cells were not detected in the SE at this time point, as $3 \mathrm{~d}$ is too soon to see proliferating SCs differentiate into HCs (Roberson et al., 2004). The highest density of proliferating SCs is seen in the mid-base region (Table 3), the region in which $\mathrm{HC}$ loss is also most pronounced (Fig. 5). Proliferation is more prominent in abneural than neural regions $(p<0.05)$ (Table 3). Proliferating SC density relative to HC density is plotted in Figure 6. Regression analysis of these data shows a linear fit with a high correlation factor $\left(r^{2}=0.83\right)$. The $y$ intercept of the linear regression analysis predicts an average HC density of 1.1 HCs per $100 \mu \mathrm{m}^{2}$ when the SE is quiescent, which correlates well with HC density quantified for our fresh noncultured tissue, $1.3 \pm 0.1 \mathrm{SEM}$. HCs per $100 \mu \mathrm{m}^{2}$. Extrapolation of the regression line to the $x$ intercept predicts 0.4 proliferating SCs per $100 \mu \mathrm{m}^{2}$ when the SE is completely denuded of HCs, i.e., HC loss equals $100 \%$. Given the overall SC density of $2.8 \pm 0.1$ SEM. SCs per 100 $\mu \mathrm{m}^{2}$ (Table 3 ), this suggests only $15 \%$ of the total SC population is stimulated to proliferate when all HCs have been lost from the SE. This number is similar to the $16 \%$ reported by Roberson and colleagues (1996) for chicken basilar papilla $5 \mathrm{~d}$ after in vivo gentamicin-induced $\mathrm{HC}$ loss in which a cell proliferation marker was administered continuously by osmotic pump.

\section{Blocking Acvr2a and Acvr2b signaling concurrently attenuates progenitor proliferation in cultured chicken auditory SE}

We sought to determine whether activin type II receptors in chicken auditory SE are involved in regulating SC proliferation. To examine this, we blocked signaling through the endogenous receptors by adding soluble recombinant activin type II receptor chimeras to the culture medium. These chimeras are comprised of either the extracellular domain of Acvr2a or Acvr2b fused to the Fc domain of an Ig and will be referred to as Fc:Acvr2a and Fc:Acvr2b. Signaling is blocked because the chimeric proteins bind Acvr2a- and Acvr2b-specific ligands with high affinity, hence inhibiting any endogenous downstream signaling events (Greenwald et al., 1998; Donaldson et al., 1999). Basilar papillae were cultured for $3 \mathrm{~d}$ in medium supplemented with Fc:Acvr2a, Fc:Acvr2b, and BrdU. Controls were cultured identically in medium that lacked the soluble receptors. A cultured control papilla is shown in Figure 7A. A comparably located region from a papilla cultured in the presence of $1.0 \mu \mathrm{g} / \mathrm{ml} \mathrm{Fc:Acvr2a}$ and 1.0 $\mu \mathrm{g} / \mathrm{ml} \mathrm{Fc:Acvr2b}$ is shown in Figure $7 B$. Sox2-labeled SCs are red in color, and BrdU-labeled nuclei are green in color. The $\mathrm{BrdU}^{+} /$ Sox $2^{+}$nuclei are easily distinguishable from the $\mathrm{BrdU}^{-} / \mathrm{Sox}^{+}$ nuclei. Note that fewer $\mathrm{BrdU}^{+} / \mathrm{Sox}^{+}{ }^{+}$nuclei are present in the SE of the experimental papilla than in the control. The decrease in the number of SCs synthesizing DNA in the soluble receptorsupplemented vis-à-vis control explants was quantitatively assessed. As shown in Figure 8, 1.0 and $1.5 \mu \mathrm{g} / \mathrm{ml}$ soluble-receptor attenuated SC proliferation by $>50 \%$ when compared with untreated controls $(p<0.05)$. Blocking signaling though a different type II receptor, TGF $\beta$ R2, with Fc:TGF $\beta$ R2 $(1.0 \mu \mathrm{g} / \mathrm{ml})$ failed to alter SC proliferation $(p>0.05)$; indicating that the effect seen with the soluble activin receptors is not an artifact of the chimeric protein itself.

It is conceivable that the effects on proliferation could be due to changes in activin receptor expression (e.g., downregulation) during the culture period. To address this possibility, Acvr2a and Acvr $2 \mathrm{~b}$ expression was assessed by immunocytochemistry after culture alone (no factors added). Acvr2a and Acvr2b receptor labeling is unchanged in cultured tissue from that in fresh noncultured tissue (data not shown), suggesting the effects on proliferation are not due to changes in receptor expression level.

Several mechanisms could explain the attenuation of SC proliferation by blocking activin signaling. First, activin receptor signaling may potentiate SC proliferation, thus blocking signaling would result in attenuation of that proliferation. Alternatively, the soluble receptors may be cytotoxic to SCs, thereby reducing the number of proliferating SCs. It is also possible that the soluble receptors may increase HC survival, which results in decreased SC proliferation. To address HC survival, we further analyzed the confocal images used for the soluble-receptor experiment analysis and quantified HCs. We reasoned that equivalent HC numbers in treated and control cultures would rule out both latter possibilities, because it is well established that HCs are considerably more susceptible to a large variety of insults than SCs, and insults that cause SC death but not HC death have not been reported. Overall HC density is similar in control and treated organs at the highest concentration of soluble receptor used (control $=0.8 \pm 0.2$ SEM. HCs $/ 100 \mu \mathrm{m}^{2}, n=32 ; 1.5 \mathrm{mg} / \mathrm{ml}$ Fc:Acvr2a/Fc:Acvr2b $=0.9 \pm 0.03 \mathrm{HCs} / 100 \mu \mathrm{m}^{2}, n=12 ; p>$ $0.05)$. Collectively, these data and the presence of the receptors and phosphorylated Smads in the SCs, suggest that activin receptor signaling directly impacts SC proliferation in mature avian auditory SE. 
Table 2. HC and SC densities and SC/HC ratios in freshly dissected, noncultured basilar papillae $(n=8)$ from P7-P14 chickens

\begin{tabular}{|c|c|c|c|c|c|c|}
\hline & Overall & Apex & Mid-apex & Mid-base & Neural & $\overline{\text { Abneural }}$ \\
\hline Average number of HCs per $100 \mu \mathrm{m}^{2}$ & $1.3 \pm 0.1$ & $1.3 \pm 0.1$ & $1.2 \pm 0.1^{*}$ & $1.0 \pm 0.1^{*}$ & $1.3 \pm 0.1$ & $1.1 \pm 0.1$ \\
\hline Average number of SCs per $100 \mu \mathrm{m}^{2}$ & $2.7 \pm 0.1$ & $2.8 \pm 0.1$ & $2.8 \pm 0.2$ & $2.7 \pm 0.2$ & $2.7 \pm 0.1$ & $2.8 \pm 0.1$ \\
\hline SC/HC ratio & 2.3 & 2.2 & 2.3 & 2.7 & 2.1 & 2.6 \\
\hline
\end{tabular}

*Significantly different from apex; $p<0.05$. Values are mean density \pm SEM.

Table 3. HC, SC ${ }^{a}$, and proliferating SC densities and SC/HC ratios in basilar papillae $(n=8)$ from P7-P14 chickens cultured for $3 \mathrm{~d}$ in the presence of the cell proliferation marker BrdU

\begin{tabular}{|c|c|c|c|c|c|c|}
\hline & Overall & Apex & Mid-apex & Mid-base & Neural & Abneural \\
\hline Average number of HCs per $100 \mu \mathrm{m}^{2}$ & $0.7 \pm 0.1$ & $1.1 \pm 0.1$ & $0.7 \pm 0.0^{*}$ & $0.3 \pm 0.1^{*}$ & $0.9 \pm 0.0$ & $0.9 \pm 0.0$ \\
\hline Average number of $S \mathrm{Cs}^{a}$ per $100 \mu \mathrm{m}^{2}$ & $2.8 \pm 0.1$ & $2.8 \pm 0.2$ & $2.6 \pm 0.0$ & $3.0 \pm 0.3$ & $2.6 \pm 0.1$ & $2.8 \pm 0.2$ \\
\hline $\mathrm{SC}^{a} / \mathrm{HC}$ ratio & 4.0 & 2.6 & 3.7 & 10.0 & 2.9 & 3.1 \\
\hline Average number of proliferating SCs per $100 \mu \mathrm{m}^{2}$ & $0.1 \pm 0.1$ & $0.07 \pm 0.0$ & $0.1 \pm 0.0^{*}$ & $0.3 \pm 0.1^{*}$ & $0.1 \pm 0.0$ & $0.9 \pm 0.0$ \\
\hline
\end{tabular}

Values are mean density \pm SEM. ${ }^{*}$ Significantly different from apex; $p<0.05$.

${ }^{a}$ All SCS, both nonproliferating and proliferating.

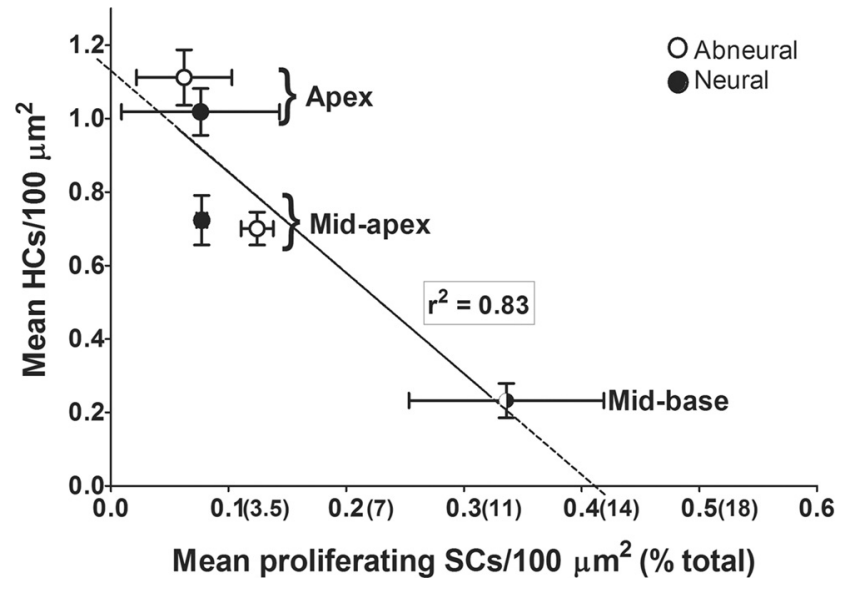

Figure 6. Relationship between hair cell density and proliferating support cell density in organotypic cultures of normal chicken auditory sensory epithelium. Untreated (control) basilar papillae grown in culture for $3 \mathrm{~d}(n=32)$ in the presence of the cell proliferation marker BrdU were immunolabeled for BrdU and Sox2 and counterstained with DAPI. Hair cell density and proliferating support cell density were determined in five regions of each papilla (Fig. 1, regions $A$ to E). Average density values computed for each region are plotted (neural apex, region $A$; abneural apex, region B; neural mid-apex, region C; abneural mid-apex, region D; mid-base, region $\mathrm{E}$ ) with each data point representing the mean $\pm \mathrm{SEM}$. The solid line is a linear regression function, fitted to points between 0.07 and 0.3 proliferating SCs per $100 \mu \mathrm{m}^{2}$. The dotted portion of the line represents predicted values. The $x$ and $y$ intercepts are 0.4 and 1.1, respectively, and the slope of the function equals -0.37 . Numbers in parentheses on the $x$ axis indicate percentages of proliferating SCS, calculated as follows: \% proliferating SCS = (mean proliferating SC density/mean total SC density) $\times 100$.

\section{Activin A potentiates SC proliferation in cultured chicken auditory $S E$}

We next sought to determine whether an activin receptor-specific ligand could potentiate proliferation, as was suggested by the previous data. The ligand activin A binds Acvr2a and Acvr2b, and we examined whether the addition of exogenous activin A could potentiate SC proliferation. As shown in Figure 9, activin A stimulates SC proliferation in cultured chicken auditory SE. Ligand concentrations of 50 and $100 \mathrm{ng} / \mathrm{ml}$ potentiated SC proliferation twofold relative to that in untreated controls ( $p=0.04$ and 0.02 , respectively) (Fig. 10). The strongest proliferative response was seen in the apex with 4 - and 15 -fold increases at 50 and $100 \mathrm{ng} / \mathrm{ml}$ treatments, respectively. Average HC counts from control cultures and those treated with $100 \mathrm{ng} / \mathrm{ml}$ activin A show no significant difference $(p=0.91)$, further supporting a role for activin signaling directly regulating SC proliferation.

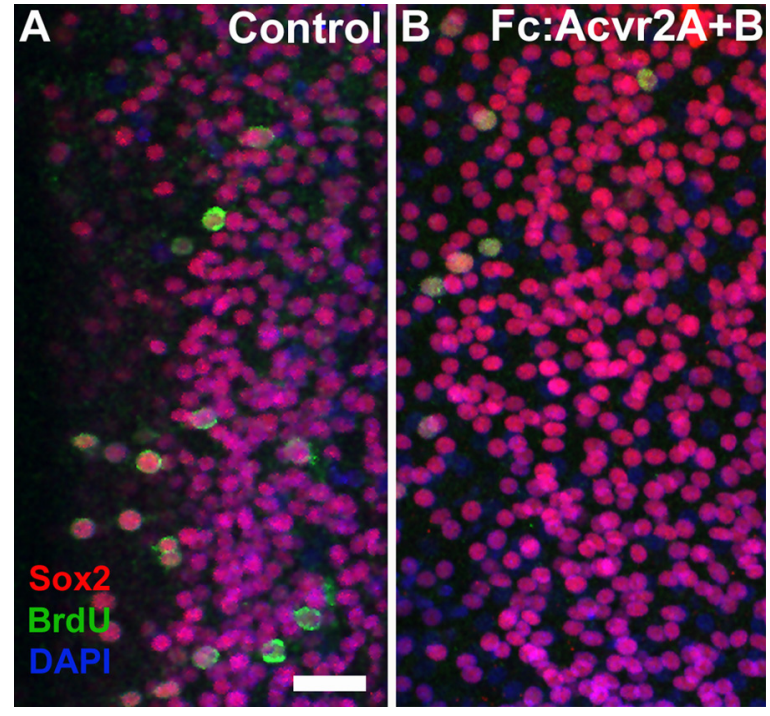

Figure 7. Blocking Acvr2 receptor signaling decreases support cell proliferation in cultured chicken auditory sensory epithelium. $\boldsymbol{A}, \boldsymbol{B}$, Photomicrographs of normal chicken basilar papilla grown in culture for $3 \mathrm{~d}$ in medium alone $(\boldsymbol{A})$ and in medium supplemented simultaneously with the soluble receptors Fc:Acvr2a and Fc:Acvr2b, which bind Acvr2a/b-specific ligands with high affinity $(\boldsymbol{B})$. BrdU was present the entire culture period. Tissues are labeled with antibody specific to Sox2 (red), an antibody specific to BrdU (green), and the nuclear counterstain DAPI (blue). The plane of focus is at the level of the $\mathrm{SC}$ nuclei. Images are from the mid-apex region. Fewer BrdU ${ }^{+} / \mathrm{Sox2}^{+}$cells are present in the supplemented culture than in the unsupplemented control. Scale bar: (in $\boldsymbol{A}) \boldsymbol{A}, \boldsymbol{B}, 20 \mu \mathrm{m}$.

Quantitative real-time PCR (qRT-PCR) was used to verify activin A mRNA expression in normal posthatch chicken auditory $\mathrm{SE}$ and $4 \mathrm{~d}$ after a gentamicin treatment that denudes the high-frequency region of the papilla of HCs. Transcripts for activin $\mathrm{A}$, the housekeeping gene $\beta$-actin, and the positive control gene $\beta$-tectorin were quantified by qRT-PCR. Beta-tectorin has been confirmed as a gene expressed in normal posthatch chicken auditory SE (Daudet et al., 2009). Comparison of activin A mRNA expression with that for $\beta$-actin indicates that the ligand is present in normal chicken auditory SE, and it is expressed twofold higher in chickens recovering from gentamicin treatment, further confirming the role for activin receptor signaling in these tissues. Collectively, these findings support that activin A and the activin receptors, Acvr2a and Acvr2b, are likely involved in initiating a mitotic signaling cascade within chicken SCs. 


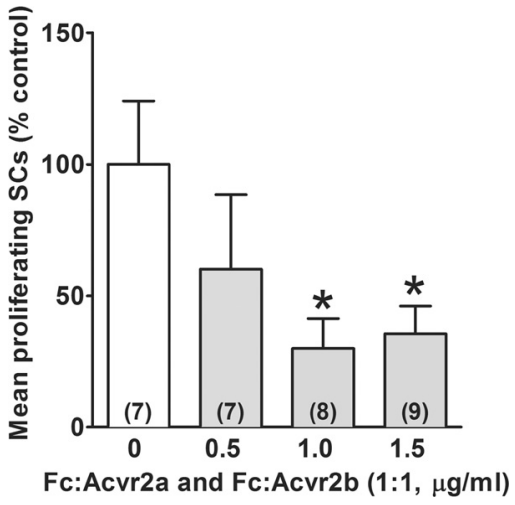

Figure 8. Quantification of the effects of blocking activin receptor signaling. Basilar papillae taken from normal posthatch chickens were cultured for $3 \mathrm{~d}$ in the absence (control) or presence of the soluble receptors Fc:Acvr2a and Fc:Acvr2b (1:1). BrdU was present the entire culture period. Proliferating support cells (Sox2 ${ }^{+} / \mathrm{BrdU}^{+}$cells) were quantified using the nonbiased random sampling described in Materials and Methods. Each data value represents the mean (expressed as percentage change relative to control) \pm SEM. Soluble activin receptor chimeras at $1.0 \mu \mathrm{g} / \mathrm{ml}$ and $1.5 \mu \mathrm{g} / \mathrm{ml}$ concentrations attenuate $\mathrm{SC}$ proliferation. An asterisk indicates values significantly different from control at the 0.05 level. Numbers of cultured organs $(n)$ are indicated in parentheses. Data are from five independent experiments.

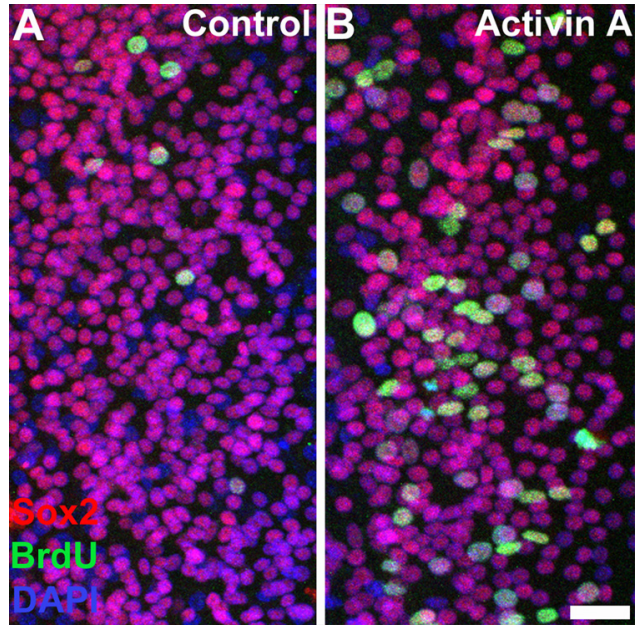

Figure 9. Exogenous activin A increases support cell proliferation in cultured chicken auditory sensory epithelium. $A, B$, Photomicrographs of normal chicken basilar papilla grown in culture for $3 \mathrm{~d}$ in medium alone $(\boldsymbol{A})$ and in medium supplemented with $100 \mathrm{ng} / \mathrm{ml}$ activin $\mathrm{A}(\boldsymbol{B})$. BrdU was present the entire culture period. Tissues are labeled with antibody specific to Sox2 (red), an antibody specific to BrdU (green), and the nuclear counterstain DAPI (blue). The plane of focus is at the level of the $\mathrm{SC}$ nuclei. Images are from the mid-apex region. Many BrdUpositive/Sox2-positive cells are present in the activin A-supplemented cultures, in contrast to the unsupplemented controls. Scale bar: (in $\boldsymbol{B}) \boldsymbol{A}, \boldsymbol{B}, 20 \mu \mathrm{m}$.

\section{Activin receptor expression differs in adult mouse inner ear sensory epithelia}

In contrast to birds, $\mathrm{HC}$ loss does not stimulate regenerative proliferation in mature mammalian auditory SE, the organ of Corti (Sobkowicz et al., 1992, 1996, 1997; Roberson and Rubel, 1994; Chardin and Romand, 1995). However, modest proliferation is seen in adult mammalian vestibular SE after aminoglycosideinduced HC loss, mechanical trauma, or growth-factor treatment (Warchol et al., 1993; Lambert, 1994; Yamashita and Oesterle, 1995; Kuntz and Oesterle, 1998; Oesterle et al., 2003). These differences might be attributable to differences in TGF $\beta$ superfamily signaling. We hypothesized that activin receptors may not be expressed in mature organ of Corti, but are present in mammalian vestibular SCs given their modest proliferative capacity. To

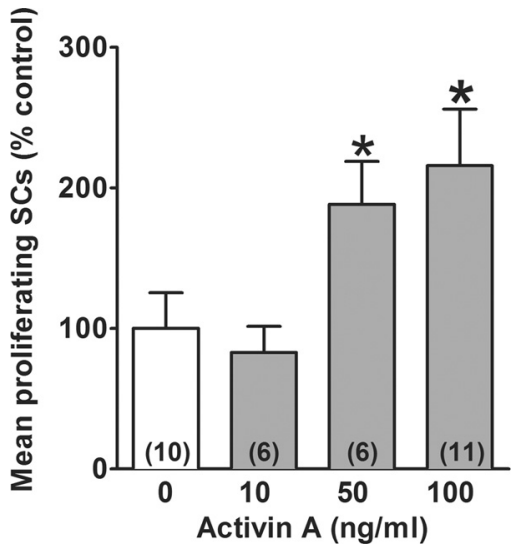

Figure 10. Quantification of activin A's effects on support cell proliferation. Basilar papillae taken from normal posthatch chickens were cultured for $3 \mathrm{~d}$ in the absence (control) or presence of the ligand activin A. BrdU was present the entire culture period. Proliferating support cells (Sox2 ${ }^{+} / \mathrm{BrdU}^{+}$cells) were quantified using the nonbiased random sampling method. Each data value represents the mean (expressed as percentage change relative to control) $\pm S E M$. Activin A (at 50 and $100 \mathrm{ng} / \mathrm{ml}$ ) potentiates support cell proliferation. Asterisks indicate values significantly different from control at the 0.05 level. Numbers of cultured organs $(n)$ are indicated in parentheses. Data are from three independent experiments.

investigate this, activin receptor expression was examined in adult mouse inner ear using immunocytochemistry. In the organ of Corti, Acvr2a immunoreactivity is not detectable in SCs, but peripheral neural processes to inner and outer HCs are immunolabeled (Fig. 11 A,B). Spiral ganglion cell bodies are also immunolabeled (data not shown). Acvr2b is expressed specifically in a subset of organ of Corti SCs, in inner and outer pillar cells (Fig. $11 C, D)$. In mammalian vestibular tissue, Acvr2a is expressed in SCs, HCs, and nerve fiber processes (Fig. 12A,B). Acvr2b is strongly expressed in vestibular SCs and weakly expressed in vestibular HCs (Fig. 12C,D).

Immunolabeling for receptor-associated Smads, proteins downstream of TGF $\beta$ receptor signaling, is shown in Figure 13 for the adult mouse organ of Corti. Weak immunoreactivity to the activated pSmad2 is seen in SC and HC nuclei (Fig. 13A,B). Strong non-nuclear pSmad2 labeling occurs near the synaptic region of the inner hair cells (IHCs). Activated Smad1/5/8 (pSmad1/5/8) is expressed in SC and HC nuclei (Fig. 13C,D). In adult mouse vestibular SE, pSmad2 is weakly expressed in SC and $\mathrm{HC}$ nuclei (Fig. 14A,B), but pSmad1/5/8 expression is strong in both (Fig. 14C,D). Whole-mount preparations of organ of Corti and utricular maculae show the same cellular distribution of activin receptors and Smads (data not shown).

Expression patterns of activin receptors and Smads in mouse inner ear SE are summarized in Table 4. Unfortunately, methods are not yet available to maintain mature mammalian auditory SE in culture. Attempts to develop an in vitro system have not been able to halt the rapid $\mathrm{HC}$ and SC loss that occurs during culture. Consequently, we could not examine functional aspects of activin receptor signaling in mature mammalian auditory tissue, as was done for the avian auditory SE. Further, studies were not conducted on cultured neonatal organ of Corti, because it has been demonstrated that growth factors often have different effects on cell proliferation in neonatal versus mature mammalian vestibular SE (Hume et al., 2003; Gu et al., 2007). In contrast, the mature mammalian vestibular SE can be maintained in culture (Warchol et al., 1993; Lambert, 1994; Yamashita and Oesterle, 1995), and manipulations of activin signaling in this model system could 
provide additional insight. Our immunolabeling data show the presence of Acvr2a, Acvr2b, and downstream effectors of activin signaling in vestibular SCs and suggest a function for the activin A signaling pathway in this tissue, a tissue with modest regenerative abilities (Warchol et al., 1993; Oesterle et al., 2003). Striking differences in receptor expression in mouse and chicken auditory SE may underlie the differential proliferative capacity of these tissues.

\section{Discussion}

To the best of our knowledge, this work is the first identification of a mitogenic signaling pathway, the activin pathway, in mature vertebrate auditory SE. The major findings of this study include the following: (1) Support cells in posthatch chicken auditory SE express type II activin receptors, Acvr2a and Acvr2b, and downstream Smad signaling proteins. (2) Activin A, an Acvr2a/b ligand, is expressed in posthatch chicken auditory SE. (3) Exogenous activin A increases SC proliferation in cultured chicken auditory SE. (4) Support cell proliferation can be inhibited by blocking signaling through type II activin receptors. (5) Mammalian and chicken auditory sensory epithelia have different type II activin receptor expression patterns. We also found that the magnitude of spontaneous cultureinduced $\mathrm{HC}$ loss is linearly related to SC proliferation.

\section{Organotypic culture model}

A fundamental challenge of regeneration research is establishing an easily manipulated model to mimic common causes of $\mathrm{HC}$ loss. In vitro organotypic cultures are advantageous because the multiple cell types in the auditory SE remain intact and in correct proportions, while allowing the tissue to be manipulated pharmaceutically. Current in vitro organotypic damage paradigms rely predominately on treatment with ototoxic drugs (e.g., aminoglycosides) at concentrations that completely or severely denude the SE of HCs. Our "nonaggressive" damage paradigm relies on natural $\mathrm{HC}$ attrition during culturing; hence, the tissue is not exposed to drug and avoids potential confounding effects of aminoglycosides on signaling. It is possible that cell signaling pathways involved in restoring HCs lost to aminoglycoside damage may differ from signaling involved in restoring HCs lost to acoustic damage or presbycusis, two common causes of HC loss and hearing disability. The apical-to-basal progression of HC loss in our model resembles the gradient seen following in vivo aminoglycoside insult (for review, see Cotanche, 1999) and allows for characterization of treatment effects in regions known to be more sensitive to insult, such as the abneural and basal regions. Others have also reported an apical-to-basal gradient of HC loss in control (nonaminoglycoside-exposed) organotypic cultures of posthatch avian auditory SE (Frenz et al., 1998; Cheng et al., 2003). The basal and abneural regions in chickens, pigeons and other birds are populated predominately by short HCs (Takasaka and Smith, 1971; Tanaka and Smith, 1978). The increased cultureinduced HC loss observed in these regions probably reflects an increased sensitivity of short HCs to damage relative to tall HCs (Ryals and Rubel, 1985a), similar to the known increased vulnerability of mammalian outer hair cells (OHCs) vis-à-vis IHCs. We show that the amount of SC proliferation is linearly linked to the magnitude of culture-induced HC loss in our model. Extrapolation from the linear regression analysis suggests that when all HCs are lost $15 \%$ of the SC population would be induced to divide, which is harmonious with the $16 \%$ reported for in situ chicken basilar papilla after gentamicin-induced HC loss (Roberson et al., 1996). Our model will be useful for future in vitro studies, as it promotes sufficient SC proliferation to evaluate both increases and decreases in proliferation while avoiding potential complications associated with aminoglycoside damage. 

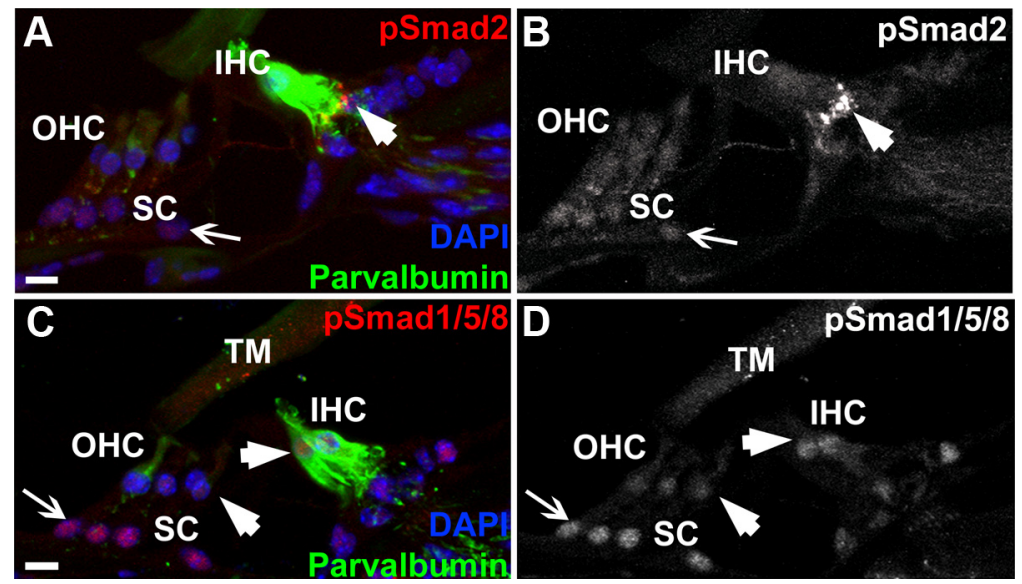

Figure 13. $\quad \mathrm{pSmad} 2$ and $\mathrm{pSmad} 1 / 5 / 8$ are expressed in adult mouse auditory sensory epithelium. Cryostat sections from normal adult mouse organ of Corti imaged with confocal microscopy. Left panels are immunolabeled for $\mathrm{pSmad} 2(\boldsymbol{A}, \mathrm{red})$ or $\mathrm{pSmad} 1 / 5 / 8$ $(\boldsymbol{C}$, red) and the HC marker parvalbumin (green) and counterstained with DAPI (blue). Right panels are the red channels (Smadspecific antibody) alone in grayscale. $\boldsymbol{A}, \boldsymbol{B}, \mathrm{pS}$ mad2 is weakly expressed in SC (arrow) and $\mathrm{HC}$ nuclei. It is strongly expressed near the IHC synaptic region (arrowhead). C, D, pSmad1/5/8 is expressed in SC (arrow) and HC nuclei (arrowheads). Artifactual, nonspecific label is present in the tectorial membrane (TM). Scale bars: $10 \mu \mathrm{m}$.
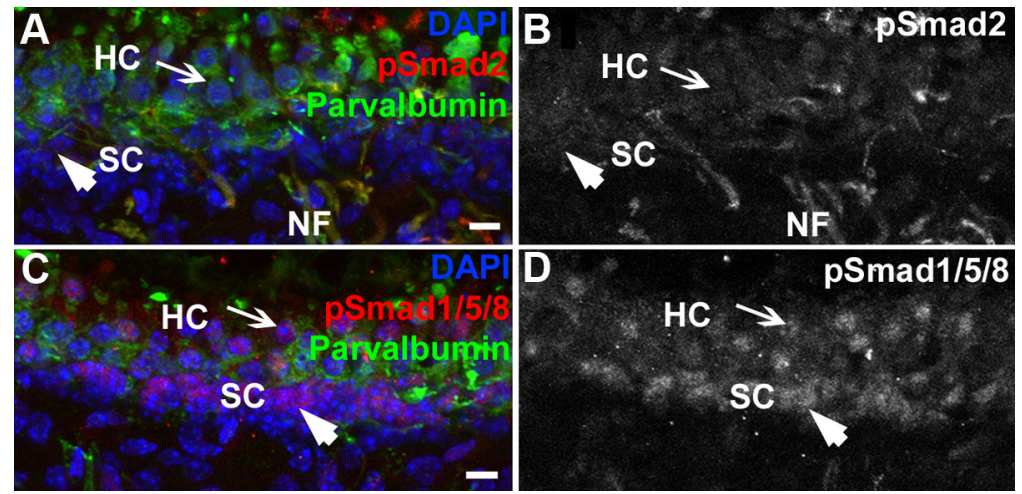

Figure 14. $\quad p S m a d 2$ and $p S m a d 1 / 5 / 8$ are expressed in adult mouse vestibular sensory epithelium. Left panels show confocal images of cryostat sections taken from normal adult mouse utricles labeled for pSmad2 $(\boldsymbol{A}$, red) or pSmad1/5/8 (C, red) and the $H \boldsymbol{C}$ marker parvalbumin (green) and counterstained with DAPI (blue). Right panels are the red channels alone (Smad-specific antibody) in grayscale. $\boldsymbol{A}, \boldsymbol{B}, \mathrm{pSmad} 2$ is weakly expressed in SC (arrowhead) and HC (arrow) nuclei and cytoplasm. It is also expressed in nerve fibers (NF). C, D, pSmad1/5/8 is expressed in SC (arrowhead) and HC (arrow) nuclei. Scale bars: $10 \mu \mathrm{m}$.

Table 4. Localization of activin receptor signaling proteins in mouse inner ear SE

\begin{tabular}{lllll}
\hline & Acvr2a & Acvr2b & pSmad2 & pSmad1/5/8 \\
\hline Auditory hair cells & - & - & + & ++ \\
Auditory support cells & - & $++^{a}$ & + & ++ \\
Vestibular hair cells & ++ & + & + & ++ \\
Vestibular support cells & ++ & ++ & + & ++ \\
\hline
\end{tabular}

++ , Strongly expressed; + , weakly expressed; - , not detected. Three to five organs were examined for each test protein.

${ }^{a}$ Pillar cells only.

\section{Activin signaling in chicken auditory SE}

TGF $\beta$ signaling pathways regulate proliferation in many tissues, including adult tissues with regenerative capacity (e.g., muscle, olfactory epithelium, skin) (McCroskery et al., 2003; Wu et al., 2003; Blanpain et al., 2004; Morris et al., 2004; Tumbar et al., 2004). Here we begin to investigate their role(s) in regulating regenerative proliferation in mature auditory SE. Our data show that SC proliferation is inhibited upon blocking activin receptor signaling, indicating activin receptor signaling is mitogenic in mature chicken auditory SE. There are other examples of activin ligands having mitogenic effects in regenerative vertebrate systems (Albertson et al., 2005; Timmer et al., 2005; Chang and Harland, 2007; Jaźwińska et al., 2007).

Ligands in the TGF $\beta$ superfamily are promiscuous, capable of binding multiple receptor complexes (for review, see Massagué, 1998; de Caestecker, 2004). It is possible that the soluble receptor used to block signaling may also absorb ligands that signal through other TGF $\beta$ type II receptors. To verify that the attenuation of proliferation was specific to the activin pathway, we show that an activin receptor-specific ligand, activin $\mathrm{A}$, directly enhances proliferation. This supports the hypothesis that activin signaling is mitogenic in mature chicken $\mathrm{SE}$ and is harmonious with data showing activin $\mathrm{A}$ can release cultured fibroblasts from quiescence (Sakurai et al., 1994). The data presented here are the first identification of a mitogenic signaling pathway in mature vertebrate auditory SE.

Activin receptors bind multiple ligands with varying effects (for review, see Harrison et al., 2005; Chen et al., 2006). Inhibitory ligands and antagonists (e.g., inhibins or follistatin) could be competing with activin $\mathrm{A}$, or other mitogenic ligands, for receptor binding to modulate proliferation. Their presence could explain why effects of activin A were not observed at lower concentrations $(10 \mathrm{ng} / \mathrm{ml})$ in the chicken auditory SE. Other activating ligands, such as activin $\mathrm{C}$, may have a more robust effect on proliferation or act concurrently to further potentiate proliferation. Because the type I TGF $\beta$ receptors, which heterodimerize with type II receptors, confer some ligand specificity to the receptor complex, identifying the type I receptors involved in regulating SC proliferation would narrow the list of possible activin receptor ligands and activin antagonists that may be involved in mediating these physiological effects.

Both receptors and downstream effectors of the activin signaling pathway are present in SCs, the cell type known to give rise to new HCs after damage. The detection of pSmad2 and pSmad1/ $5 / 8$ in SC and HC nuclei in normal mature chicken auditory SE suggests that TGF $\beta$ pathways are actively signaling during quiescence. The presence of $\mathrm{pSmad} 1 / 5 / 8$ indicates that members of the TGF $\beta$ superfamily other than Acvr2a and Acvr2b may also be active during quiescence (e.g., BMPs) (for review, see Herpin and Cunningham, 2007). It is important to note that lack of pSmad3 in normal chicken auditory SE only suggests that signaling through pSmad3 is not active under normal conditions. Smad3 cannot be excluded from a role during regeneration.

Because the activin receptors and Smads are detected in both SCs and HCs, we cannot distinguish whether effects of activin on proliferation are via SCs, HCs, or both. Hair cells and SCs could have different receptor heterodimer configurations (i.e., couple with different type 1 receptors) and subsequently have different 
roles in signaling. Or, activin signaling could have a similar role on both cell types, causing release of a factor that promotes SC proliferation with either an autocrine or paracrine mechanism. As shown in this report, exogenous activin A has a mitogenic effect in mature auditory SE, but future work is needed to elucidate the specificities of the signaling involved.

\section{Does the increased SC proliferation lead to hair cell regeneration?}

It is conceivable that activin A-triggered SC proliferation may not lead to production of new HCs. The newly generated cells could remain as SCs or die off shortly after generation. Many SCs generated mitotically after aminoglycoside insult in cultured avian inner ear go on to differentiate as HCs (Stone et al., 1996, Matsui et al., 2000). Further, isolated SCs from neonatal mouse cochlea maintain ability to differentiate into $\mathrm{HCs}$ following cell division (White et al., 2006). On the other hand, cells generated mitotically in adult guinea pig utricle failed to differentiate into HCs (Rubel et al., 1995). Long-duration culture studies will be needed to determine whether the new cells survive and differentiate as HCs. Nevertheless, the identification of mitogenic factors for SCs alone is critically important, as effective therapeutic strategies in humans are likely to require generation of both new HCs and SCs. The ability to induce SC proliferation could be an important component of a transdifferentiation therapy in which the SC population needs to be replenished following the transdifferentiation of SCs into new HCs, because HCs require trophic support from SCs to survive.

\section{Activin signaling in mammalian inner ear}

Unlike chicken, in mouse organ of Corti, Acvr2a appears to be strictly neurally localized. It is possible that the antibody is crossreacting with a conserved epitope in a neural-specific splice variant of Acvr2a, Acvr2a-N, identified in brain and spinal cord in adult mouse, human and Xenopus, but little is known regarding its specific function (Shoji et al., 1998). The Acvr2b receptor also has a unique distribution in mouse auditory SE, localized to pillar cells only. This contrasts with chicken, in which the receptor is expressed in all SCs and HCs.

Mammalian vestibular SE and chicken auditory SE are both normally quiescent tissues that maintain some proliferative capabilities into maturity (for review, see Oesterle and Stone, 2008). Interestingly, pSmad 2 and Acvr2a are expressed in SCs in these tissues, but not in the organ of Corti. The differential expression of activin receptors and $\mathrm{pSmad} 2$ in the nonproliferative mouse auditory SE versus regenerative chicken auditory SE could account for some of the differences in proliferative potential between these sensory tissues.

In conclusion, TGF $\beta$ signaling pathways are potent regulators of progenitor cell proliferation for many adult tissues. The multifaceted data presented here indicate that activin signaling regulates SC proliferation in mature chicken auditory SE.

\section{References}

Albertson RC, Payne-Ferreira TL, Postlethwait J, Yelick PC (2005) Zebrafish acvr2a and acvr2b exhibit distinct roles in craniofacial development. Dev Dyn 233:1405-1418.

Bermingham-McDonogh O, Rubel EW (2003) Hair cell regeneration: winging our way towards a sound future. Curr Opin Neurobiol 13:119-126.

Blanpain C, Lowry WE, Geoghegan A, Polak L, Fuchs E (2004) Self-renewal, multipotency, and the existence of two cell populations within an epithelial stem cell niche. Cell 118:635-648.

Chang C, Harland RM (2007) Neural induction requires continued sup- pression of both Smad1 and Smad 2 signals during gastrulation. Development 134:3861-3872.

Chardin S, Romand R (1995) Regeneration and mammalian auditory hair cells. Science 267:707-711.

Chen YG, Wang Q, Lin SL, Chang CD, Chuang J, Ying SY (2006) Activin signaling and its role in regulation of cell proliferation, apoptosis, and carcinogenesis. Exp Biol Med (Maywood) 231:534-544.

Cheng AG, Cunningham LL, Rubel EW (2003) Hair cell death in the avian basilar papilla: characterization of the in vitro model and caspase activation. J Assoc Res Otolaryngol 4:91-105.

Corwin JT, Cotanche DA (1988) Regeneration of sensory hair cells after acoustic trauma. Science 240:1772-1774.

Corwin JT, Oberholtzer JC (1997) Fish n' chicks: model recipes for hair cell regeneration? Neuron 19:951-954.

Cotanche DA (1999) Structural recovery from sound and aminoglycoside damage in the avian cochlea. Audiol Neurootol 4:271-285.

Daudet N, Gibson R, Shang J, Bernard A, Lewis J, Stone J (2009) Notch regulation of progenitor cell behavior in quiescent and regenerating auditory epithelium of mature birds. Dev Biol 326:86-100.

de Caestecker M (2004) The transforming growth factor-beta superfamily of receptors. Cytokine Growth Factor Rev 15:1-11.

Donaldson CJ, Vaughan JM, Corrigan AZ, Fischer WH, Vale WW (1999) Activin and inhibin binding to the soluble extracellular domain of activin receptor II. Endocrinology 140:1760-1766.

Duckert LG, Rubel EW (1993) Morphological correlates of functional recovery in the chicken inner ear after gentamycin treatment. J Comp Neurol 331:75-96.

Franke AG, Gubbe C, Beier M, Duenker N (2006) Transforming growth factor-beta and bone morphogenetic proteins: cooperative players in chick and murine programmed retinal cell death. J Comp Neurol 495:263-278.

Frenz DA, Yoo H, Liu W (1998) Basilar papilla explants: a model to study hair cell regeneration-repair and protection. Acta Otolaryngol 118:651-659.

Giannouli CC, Kletsas D (2006) TGF-[beta] regulates differentially the proliferation of fetal and adult human skin fibroblasts via the activation of PKA and the autocrine action of FGF-2. Cell Signal 18:1417-1429.

Girod DA, Duckert LG, Rubel EW (1989) Possible precursors of regenerated hair cells in the avian cochlea following acoustic trauma. Hear Res 42:175-194.

Girod DA, Tucci DL, Rubel EW (1991) Anatomical correlates of functional recovery in the avian inner ear following aminoglycoside ototoxicity. Laryngoscope 101:1139-1149.

Goldstein AM, Brewer KC, Doyle AM, Nagy N, Roberts DJ (2005) BMP signaling is necessary for neural crest cell migration and ganglion formation in the enteric nervous system. Mech Dev 122:821-833.

Goodyear R, Richardson G (1997) Pattern formation in the basilar papilla: evidence for cell rearrangement. J Neurosci 17:6289-6301.

Gratzner HG (1982) Monoclonal antibody to 5-bromo- and 5-iododeoxyuridine: a new reagent for detection of DNA replication. Science 218:474-475.

Greenwald J, Le V, Corrigan A, Fischer W, Komives E, Vale W, Choe S (1998) Characterization of the extracellular ligand-binding domain of the type II activin receptor. Biochemistry 37:16711-16718.

Gu R, Montcouquiol M, Marchionni M, Corwin JT (2007) Proliferative responses to growth factors decline rapidly during postnatal maturation of mammalian hair cell epithelia. Eur J Neurosci 25:1363-1372.

Harrison CA, Gray PC, Vale WW, Robertson DM (2005) Antagonists of activin signaling: mechanisms and potential biological applications. Trends Endocrinol Metab 16:73-78.

Hasson T, Mooseker MS (1994) Porcine myosin-VI: characterization of a new mammalian unconventional myosin. J Cell Biol 127:425-440.

Hasson T, Gillespie PG, Garcia JA, MacDonald RB, Zhao Y, Yee AG, Mooseker MS, Corey DP (1997) Unconventional myosins in inner-ear sensory epithelia. J Cell Biol 137:1287-1307.

Heldin C (2008) TGF- $\beta$ signaling from receptors to Smads. In: The TGF- $\beta$ family (Derynck R, Miyazono K, eds). Cold Spring Harbor, NY: Cold Spring Harbor Laboratory.

Herpin A, Cunningham C (2007) Cross-talk between the bone morphogenetic protein pathway and other major signaling pathways results in tightly regulated cell-specific outcomes. FEBS J 274:2977-2985.

Hume CR, Kirkegaard M, Oesterle EC (2003) ErbB expression: the mouse 
inner ear and maturation of the mitogenic response to heregulin. J Assoc Res Otolaryngol 4:422-443.

Hume CR, Bratt DL, Oesterle EC (2007) Expression of LHX3 and SOX2 during mouse inner ear development. Gene Expr Patterns 7:798-807.

Jaźwińska A, Badakov R, Keating MT (2007) Activin-betaA signaling is required for zebrafish fin regeneration. Curr Biol 17:1390-1395.

Kawase Y, Yanagi Y, Takato T, Fujimoto M, Okochi H (2004) Characterization of multipotent adult stem cells from the skin: transforming growth factor-beta (TGF-beta) facilitates cell growth. Exp Cell Res 295:194-203.

Kos K, Fine L, Coulombe JN (2001) Activin type II receptors in embryonic dorsal root ganglion neurons of the chicken. J Neurobiol 47:93-108.

Kuntz AL, Oesterle EC (1998) Transforming growth factor alpha with insulin stimulates cell proliferation in vivo in adult rat vestibular sensory epithelium. J Comp Neurol 399:413-423.

Lambert PR (1994) Inner ear hair cell regeneration in a mammal: identification of a triggering factor. Laryngoscope 104:701-718.

Li Q, Karam SM, Coerver KA, Matzuk MM, Gordon JI (1998) Stimulation of activin receptor II signaling pathways inhibits differentiation of multiple gastric epithelial lineages. Mol Endocrinol 12:181-192.

Massagué J (1998) TGF-beta signal transduction. Annu Rev Biochem 67:753-791.

Massagué J, Gomis RR (2006) The logic of TGFbeta signaling. FEBS Lett 580:2811-2820.

Massagué J, Blain SW, Lo RS (2000) TGFbeta signaling in growth control, cancer, and heritable disorders. Cell 103:295-309.

Massagué J, Seoane J, Wotton D (2005) Smad transcription factors. Genes Dev 19:2783-2810.

Mathews LS, Vale WW (1993) Characterization of type II activin receptors. Binding, processing, and phosphorylation. J Biol Chem 268:1901319018.

Matsui JI, Oesterle EC, Stone JS, Rubel EW (2000) Characterization of damage and regeneration in cultured avian utricles. J Assoc Res Otolaryngol 1:46-63.

McCroskery S, Thomas M, Maxwell L, Sharma M, Kambadur R (2003) Myostatin negatively regulates satellite cell activation and self-renewal. J Cell Biol 162:1135-1147.

Montero JA, Lorda-Diez CI, Gañan Y, Macias D, Hurle JM (2008) Activin/ TGF $\beta$ and BMP crosstalk determines digit chondrogenesis. Dev Biol 321:343-356.

Morris RJ, Liu Y, Marles L, Yang Z, Trempus C, Li S, Lin JS, Sawicki JA, Cotsarelis G (2004) Capturing and profiling adult hair follicle stem cells. Nat Biotechnol 22:411-417.

Oesterle EC, Stone JS (2008) Hair cell regeneration: mechanisms guiding cell proliferation and differentiation. In: Hair cell regeneration, repair, and protection (Salvi RJ, Popper AN, Fay NN, eds), pp 141-197. New York: Springer.

Oesterle EC, Tsue TT, Reh TA, Rubel EW (1993) Hair-cell regeneration in organ cultures of the postnatal chicken inner ear. Hear Res 70:85-108.

Oesterle EC, Bhave SA, Coltrera MD (2000) Basic fibroblast growth factor inhibits cell proliferation in cultured avian inner ear sensory epithelia. J Comp Neurol 424:307-326.

Oesterle EC, Cunningham DE, Westrum LE, Rubel EW (2003) Ultrastructural analysis of $[3 \mathrm{H}]$ thymidine-labeled cells in the rat utricular macula. J Comp Neurol 463:177-195.

Oesterle EC, Campbell S, Taylor RR, Forge A, Hume CR (2008) Sox2 and Jagged 1 expression in normal and drug-damaged adult mouse inner ear. J Assoc Res Otolaryngol 9:65-89.

Pleis JR, Schiller JS, Benson V (2003) Summary health statistics for U.S. adults: National Health Interview Survey, 2000. Vital Health Stat $10: 1-132$.

Pleis JR, Lethbridge-Cejku M (2006) Summary health statistics for U.S. adults: National Health Interview Survey, 2005. Vital Health Stat 10:1-153.

Rajagopal R, Ishii S, Beebe DC (2007) Intracellular mediators of transforming growth factor $\beta$ superfamily signaling localize to endosomes in chicken embryo and mouse lenses in vivo. BMC Cell Biol 8:25.

Reynolds LE, Conti FJ, Lucas M, Grose R, Robinson S, Stone M, Saunders G, Dickson C, Hynes RO, Lacy-Hulbert A, Hodivala-Dilke K (2005) Accelerated re-epithelialization in beta3-integrin-deficient- mice is associated with enhanced TGF-beta1 signaling. Nat Med 11:167-174.
Rios I, Alvarez-Rodríguez R, Martí E, Pons S (2004) Bmp2 antagonizes sonic hedgehog-mediated proliferation of cerebellar granule neurones through Smad5 signalling. Development 131:3159-3168.

Roberson DW, Rubel EW (1994) Cell division in the gerbil cochlea after acoustic trauma. Am J Otol 15:28-34.

Roberson DW, Krieg S, Rubel EW (1996) Light microscopic evidence that direct transdifferentiation gives rise to new hair cells in regenerating avian auditory epithelium. Aud Neurosci 2:195-205.

Roberson DW, Alosi JA, Cotanche DA (2004) Direct transdifferentiation gives rise to the earliest new hair cells in regenerating avian auditory epithelium. J Neurosci Res 78:461-471.

Rubel EW, Dew LA, Roberson DW (1995) Mammalian vestibular hair cell regeneration. Science 267:701-707.

Ryals BM, Rubel EW (1982) Patterns of hair cell loss in chick basilar papilla after intense auditory stimulation. Frequency organization. Acta Otolaryngol 93:205-210.

Ryals BM, Rubel EW (1985a) Differential susceptibility of avian hair cells to acoustic trauma. Hear Res 19:73-84.

Ryals BM, Rubel EW (1985b) Ontogenetic changes in the position of hair cell loss after acoustic overstimulation in avian basilar papilla. Hear Res 19:135-142.

Ryals BM, Rubel EW (1988) Hair cell regeneration after acoustic trauma in adult Coturnix quail. Science 240:1774-1776.

Sage C, Ventéo S, Jeromin A, Roder J, Dechesne CJ (2000) Distribution of frequenin in the mouse inner ear during development, comparison with other calcium-binding proteins and synaptophysin. Hear Res 150:70-82.

Sakurai T, Abe Y, Kasuya Y, Takuwa N, Shiba R, Yamashita T, Endo T, Goto K (1994) Activin A stimulates mitogenesis in Swiss 3 T3 fibroblasts without activation of mitogen-activated protein kinases. J Biol Chem 269:14118-14122.

Shoji H, Nakamura T, van den Eijnden-van Raaij AJ, Sugino H (1998) Identification of a novel type II activin receptor, type IIA-N, induced during the neural differentiation of murine P19 embryonal carcinoma cells. Biochem Biophys Res Commun 246:320-324.

Smolders JW (1999) Functional recovery in the avian ear after hair cell regeneration. Audiol Neurootol 4:286-302.

Sobkowicz HM, August BK, Slapnick SM (1992) Epithelial repair following mechanical injury of the developing organ of Corti in culture: an electron microscopic and autoradiographic study. Exp Neurol 115:44-49.

Sobkowicz HM, August BK, Slapnick SM (1996) Post-traumatic survival and recovery of the auditory sensory cells in culture. Acta Otolaryngol 116:257-262.

Sobkowicz HM, August BK, Slapnick SM (1997) Cellular interactions as a response to injury in the organ of Corti in culture. Int J Dev Neurosci 15:463-485.

Son ED, Lee JY, Lee S, Kim MS, Lee BG, Chang IS, Chung JH (2005) Topical application of 17beta-estradiol increases extracellular matrix protein synthesis by stimulating tgf-Beta signaling in aged human skin in vivo. J Invest Dermatol 124:1149-1161.

Stone JS, Cotanche DA (2007) Hair cell regeneration in the avian auditory epithelium. Int J Dev Biol 51:633-647.

Stone JS, Leaño SG, Baker LP, Rubel EW (1996) Hair cell differentiation in chick cochlear epithelium after aminoglycoside toxicity: in vivo and in vitro observations. J Neurosci 16:6157-6174.

Takasaka T, Smith CA (1971) The structure and innervation of the pigeon's basilar papilla. J Ultrastruct Res 35:20-65.

Tanaka K, Smith CA (1978) Structure of the chicken's inner ear: SEM and TEM study. Am J Anat 153:251-271.

Timmer J, Chesnutt C, Niswander L (2005) The activin signaling pathway promotes differentiation of $\mathrm{dI} 3$ interneurons in the spinal neural tube. Dev Biol 285:1-10.

Tsuchida K, Nakatani M, Uezumi A, Murakami T, Cui X (2008) Signal transduction pathway through activin receptors as a therapeutic target of musculoskeletal diseases and cancer. Endocr J 55:11-21.

Tucci DL, Rubel EW (1990) Physiologic status of regenerated hair cells in the avian inner ear following aminoglycoside ototoxicity. Otolaryngol Head Neck Surg 103:443-450.

Tumbar T, Guasch G, Greco V, Blanpain C, Lowry WE, Rendl M, Fuchs E (2004) Defining the epithelial stem cell niche in skin. Science 303: 359-363. 
Warchol ME, Corwin JT (1996) Regenerative proliferation in organ cultures of the avian cochlea: identification of the initial progenitors and determination of the latency of the proliferative response. J Neurosci 16:5466-5477.

Warchol ME, Lambert PR, Goldstein BJ, Forge A, Corwin JT (1993) Regenerative proliferation in inner ear sensory epithelia from adult guinea pigs and humans. Science 259:1619-1622.

White PM, Doetzlhofer A, Lee YS, Groves AK, Segil N (2006) Mammalian cochlear supporting cells can divide and trans-differentiate into hair cells. Nature 441:984-987.

Wiater E, Vale W (2008) Activins and inhibins. In: The TGF $\beta$ family (Derynck R, Miyazono K, eds), pp 79-120. Cold Spring Harbor, NY: Cold Spring Harbor Laboratory.
Wrana JL, Ozdamar B, Le Roy C, Benchabane H (2008) Signaling receptors of the TGF- $\beta$ family. In: The TGF- $\beta$ family (Derynck R, Miyazono K, eds), pp 151-177. Cold Spring Harbor, NY: Cold Spring Harbor Laboratory.

Wu HH, Ivkovic S, Murray RC, Jaramillo S, Lyons KM, Johnson JE, Calof AL (2003) Autoregulation of neurogenesis by GDF11. Neuron 37: 197-207.

Xu L (2006) Regulation of Smad activities. Biochim Biophys Acta 1759: 503-513.

Yamashita H, Oesterle EC (1995) Induction of cell proliferation in mammalian inner-ear sensory epithelia by transforming growth factor alpha and epidermal growth factor. Proc Natl Acad Sci U S A 92:31523155 . 